STUDII

\title{
DESPRE EVOLUȚIA FUNDAȚIEI \\ TESTAMENTARE ÎN DREPTUL CIVIL ROMÂN
}

DOI: $\quad 10.24193 /$ SUBBiur.65(2020).4.2

Data publicării online:

16.03 .2021

\section{Mircea-Dan BOB*}

Rezumat: Lăsarea averilor în scop pios şi caritabil a fost o constantă practică a vechiului drept românesc. A avut însă și o bază legală care să o susțină sau încurajeze? Cum se explică faptul că, abia anul 1924 a adus o reglementare expresă a fundațiilor, la șase decenii distanță de intrarea în vigoare a codului lui Cuza? Care este situația actuală? Toate aceste întrebări sunt menite să identifice răspunsuri care să clarifice o problemă centrală: există vreo soluție de continuitate în asigurarea unui cadru legal adecvat pentru încurajarea și validarea fondărilor testamentare.

Cuvinte cheie: fundație, istoria dreptului, persoană juridică, legiferare.

* Profesor, Facultatea de Drept, Universitatea Babeș-Bolyai din Cluj, mircea.bob@law.ubbcluj.ro. 


\title{
ON THE EVOLUTION OF TESTAMENTARY FOUNDATIONS IN ROMANIAN CIVIL LAW
}

\begin{abstract}
Leaving wealth for pious and charitable purposes has been a constant practice of the old Romanian law. However, did it also had a legal basis to support or encourage it? How can it be explained that only in 1924 an express regulation of foundations was created, six decades apart from the entry into force of Cuza's Civil Code? What is the current situation? All these questions are meant to identify answers that clarify a primary issue: is there any continuity solution in ensuring an adequate legal framework for encouraging and validating testamentary foundations in Romanian law.
\end{abstract}

Keywords: foundation, history of law, legal person, legiferation.

\section{Cuprins}

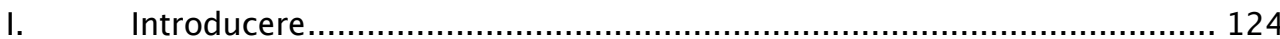

II. Vechiul drept românesc și conceptul de persoană juridică. ................... 125

III. Vechiul drept românesc și fundația testamentară............................. 127

IV. Situația în codul civil român....................................................... 129

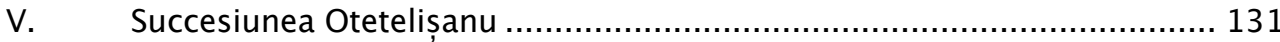

VI. Consacrarea legislativă a fundațiilor testamentare ........................... 135

VII. Există continuitate în asigurarea unui cadru legal adecvat pentru încurajarea și validarea fondărilor testamentare? ..................................................... 136 


\section{Introducere}

Cercetarea doctorală pe care am realizat-o sub îndrumarea profesorului Hanga între anii 1997 și 2000 s-a axat pe evoluția succesiunii testamentare în dreptul roman ${ }^{1}$. Am publicat apoi în anul 2002 o culegere de practică testamentară relevantă din perioada 1862-2001². România revenise la un regim politic bazat pe încurajarea proprietății private și pe libertatea iniţiativei private; am mizat pe faptul că aceasta va redeschide economic posibilitatea și va redeștepta apetitul omului de a dispune mortis causa de rezultatele muncii sale. Intuiția avută a fost bună: practica notarială indică o creștere în ultimele două decenii a numărului de succesiuni dezbătute în baza testamentelor lăsate de defuncți.

Actualitatea subiectului nu este însă motivația primară a cercetării, servindu-mi numai pentru a face legătura cu figura regretatului meu maestru, profesor doctor docent Vladimir Hanga. Rândurile de față nici nu au caracter de noutate absolută. Am reunit câteva cercetări anterioare, tocmai pentru a evidenția soluția de continuitate între începutul studiilor doctorale (sub bagheta domniei sale) și felul în care le-am valorificat, prin istoria dreptului şi dincolo de aceasta, în dreptul succesoral pozitiv. Este un modest gest prin care, ucenic și urmaș al său la catedrele de Drept Roman și de Succesiuni, încerc să arăt cum am folosit învățăturile primite.

${ }^{1}$ M.D. BocȘAn, Evoluția succesiunii testamentare în dreptul roman, teză, Lumina Lex, București, 2000, 184 p.

${ }^{2}$ M.D. BocȘAN, Practica testamentară. Jurisprudență română 1862-2001, Rosetti, București, 2002, $366 \mathrm{p}$. 
Voi puncta pentru început identitatea practică și conceptuală a fundațiilor testamentare ținând cont de dualitatea semantică dintre calitatea lor de persoane juridice și aceea de acte juridice. Voi aborda apoi nefericita lor non-identitate legislativă în modernitatea adusă de codul lui Cuza, examinând reacția practicii într-o decizie reper a instanței noastre supreme: cea dată în procesul intentat legatarului universal Ioan Kalinderu de către moștenitorii legali ai testatorului Otetelișanu. Vom examina apoi reacția legislativă la astfel de practici, pentru a veni până în actualitatea codului civil român din 2011. Întrebarea centrală la care doresc să identific un răspuns prin analizele de mai sus sună astfel: există vreo soluție de continuitate în asigurarea unui cadru legal adecvat pentru încurajarea și validarea fondărilor testamentare? Întrevăd $a b$ initio posibilitatea ca ceea ce voi descoperi pe parcurs să mă oblige la defalcarea răspunsului: există continuitate legislativă? beneficiază fondările testamentare de un cadru legislativ prielnic?

II. Vechiul drept românesc și conceptul de persoană juridică.

Prima chestiune de studiat trebuie să fie una de ordin general: cunoștea vechiul drept românesc conceptul de persoană juridică? Răspunsul ne va conduce concomitent și la fundațiile testamentare.

Caritatea post mortem exprimată prin înființarea unor așezăminte (stabilimente) cu scopuri social-educative nu a fost străină vechiului drept românesc. Testatorii au înființat entități destinate ajutorării celor în nevoie, dedicate alinării suferințelor cauzate de boli, afectate educației tinerilor, menite a culturaliza masele sau pentru a urmări scopuri politice şi, nu în ultimul rând, pentru a perpetua memoria fondatorului(-ilor). Chiar dacă acest 
tip de subiecte de drept exista deci în practică, nici documentele, nici pravilele până la Codul Calimach $(1817)^{3}$ nu au folosit noțiunea. Se pare că Pravila lui Alexandru cel Bun ar fi vorbit de anumite corporații și bresle la art. 14, 18 și 102 (fiscus), art. 10 (vicus = sat), 148, 201 (piae causae = biserica), 208 (xenodochia = sanatoriu). Existența acestora era însă numai faptică, neavând personalitate juridică. $\mathrm{Nu}$ exista vreo clasificare a respectivelor subiecte de drept din perspectiva obiectului de activitate şi al scopului. Reglementările sunt vagi și nu permit separarea dreptului public de cel privat ${ }^{4}$. Este de înțeles astfel de ce nu exista noțiunea de fundație privată de utilitate publică, utilizându-se - așa cum am precizat - noțiunile de stabiliment sau de așezământ ${ }^{5}$.

Aveau mănăstirile și bisericile personalitate juridică în postură de fundații religioase? Răspunsul afirmativ a fost întemeiat pe modul de redactare a documentelor care vizau bunurile bisericii dar și achiziția acestui gen de bunuri - care se făcea în acelaşi mod ca şi pentru persoanele fizice ${ }^{6}$. Părerea mea a fost şi este că argumentul adus este o simplă conjectură, câtă vreme dreptul lui Iustinian conține dispoziții detaliate privind bisericile, fără

\footnotetext{
${ }^{3}$ Al. Spineanu, Notă la dec.nr. 130/1922 a Cas. I, în PR 1923.I.116. Pravilniceasca Condicã (1790 - v. ediția critică a Academiei Române, București, 1957), cap. XVII §1 și Codul Caragea (1818 v. ediția critică a Academiei Române, București, 1955) III.14.1 vorbesc despre tovărăşii (asociații profesionale, bresle) pentru a desemna asociațiile negustorilor. Codul Calimach a fost primul care a definit conceptul de persoană și a folosit - tot pentru entitățile constituite de comercianți - termenul de persoane moralicești (M. Guțan, Istoria dreptului românesc ${ }^{2}$, Hamangiu, București, 2008, p. 158-159, respectiv D. Țop, O. Măstăcan, Istoria statului şi dreptului românesc, C.H. Beck, București, 2009, p. 129).

${ }^{4}$ Gh. Cronț, în Istoria dreptului românesc, vol. I ccord. Vl. Hanga, Ed. Academiei Române, București, 1980, p. 495.

${ }^{5}$ Const.Gr. Zotta, Notă la dec.nr. 508/1928 de Cas. I, în PR 1935.I.57.

${ }^{6}$ Gh. Cront, Dreptul de ctitorie în Ţara Româneascã și Moldova. Constituirea şi natura juridicã a fundațiilor din evul mediu, în Studii și materiale de istorie medie (IV) 1960, p. 101-113.
} 
a teoretiza însă conceptul juridic; niciuna din legile bizantine importate în Principatele române nu trimite la existența persoanelor morale, ci dispozițiile se prezintă în stadiul lor originar. Dacă ar fi existat conceptul, românii nu l-ar fi introdus în legile preluate și prelucrate? Un alt argument în susținerea răspunsului negativ ar fi unul de ordin documentar: documentele de sec. XVII-XVIII cuprinse în Codul lui Constantin Mavrocordat privind procesul dintre mănăstirea Hangul şi Maria Cantacuzino nu invocă codurile, ci Leviticul și obiceiurile țării ${ }^{7}$.

\section{Vechiul drept românesc și fundația testamentară}

Am stabilit până aici inexistența conceptului de persoană juridică până la enunțarea acestuia în cuprinsul Codului Calimach, cod a cărui aplicare în practică a fost oricum restrânsă $\breve{8}^{8}$. Așa cum am arătat cu altă ocazie ${ }^{9}$, se poate afirma că ceea noi numim astăzi persoane juridice luau naștere prin simpla voință a fondatorilor. Indiferent că era vorba de mănăstiri, școli, biserici, spitale sau bresle, rolul hrisovului domnesc era numai unul de confirmare şi de publicitate a situației drepturilor de proprietate ${ }^{10}$. Vechiul drept românesc

\footnotetext{
7 Documentele nr. 1312-1318, 1319-1325 și 1609-1613 "Condica lui Constantin Mavrocordat", ediția C. Istrati, vol. III, Iași, 1987.

${ }^{8}$ V. Bocşan, Evoluția..., cit.supra, p. 129-131.

${ }^{9}$ M.D. Bocșan, Observații privind conceptul de persoană juridică, în Juridica nr. 3/2001, p. 125 .

10 Realitatea așezămintelor este „o veche tradiție juridică, care se poate considera ca o prelungire și o interpretare românească a principiilor juridice bizantine” (Cronț, Dreptul..., cit.supra, p. 100).
} 
a urmat deci o libertate empirică în materie ${ }^{11}$. Putem acum să ne întrebăm: care a fost situația pentru fundațiile testamentare?

Indiferent că avem în vedere vechiul drept cutumiar sau vechile pravile și coduri anterioare momentului 1 decembrie 1865 , activitatea fundațională a fost constant validată și încurajată. Această constatare nu trebuie înțeleasă în sensul în care am percepe-o astăzi, trecând-o prin filtrul modului nostru de a vedea lucrurile. Noi avem o perspectivă legistă, în care ne raportăm mereu la o bază teoretică identificată într-un text de lege care permite sau nu o anumită decizie practică. Or, cadrul legislativ prielnic despre care scriam mai sus nu se concretiza în vechiul drept românesc în texte de lege coerente și precise, realizate pe baze teoretice prealabil identificate. Era vorba mai degrabă de o tradiție perpetuată într-un sistem de gesturi sociale și permisiuni ierarhice, cultivată de influența dominantă (spirituală și economico-politică) a bisericii ortodoxe. Cu alte cuvinte, conta mai puțin faptul că fundația testamentară este sau nu consacrată în calitate de persoană juridică, că are sau nu un regim juridic specific în reglementările legale (cutumiare sau scrise). Fundația testamentară era o realitate, nu o ficțiune juridică, iar contemporanii acelor vremuri se preocupau mai degrabă de certitudinea dispunerii pentru cauză de moarte și de primirea acesteia de către organul clerical sau de autoritatea laică.

${ }^{11}$ V. Hillard, Tendința realistă în personalitatea juridică a dreptului civil, teză, București, 1928, p. 35 . 


\section{Situația în codul civil român}

Situația s-a schimbat în plan legislativ, odată cu adoptarea primului cod civil român modern.

Noțiunea de persoană morală (juridică) fondată pe teoria ficțiunii a intrat efectiv în dreptul nostru în același timp cu preluarea masivă a Codului Napoleon: art. 811 c.civ. 1864 (corespunzând art. 910 c.civ.fr. 1804) a instituit obligativitatea autorizării prealabile a constituirii persoanelor morale și a întemeiat teoria ficțiunii acestora în comparație cu cele fizice. Codul civil de la 1864 a preluat astfel, odată cu textele, poziția ostilă a legiuitorului francez de la 1804 față de persoanele juridice.

Revoluția proclamase în 1789 în Franța abolirea privilegiilor feudale și ecleziastice și a expropriat averile de mână moartă ale bisericii catolice. Aceasta nu stătuse cu mâinile în sân: a încercat să-şi salveze pozițiile economice înființând congregații religioase, la nivel declarativ, în care urmărea de fapt să-şi pună la adăpost averile amenințate de confiscare. Ca urmare, exproprierea întinselor domenii clericale și reintroducerea acestora în circuitul civil a fost corelată cu măsuri legislative de preîntâmpinare a refacerii proprietăților neproductive: autoritatea publică trebuia să verifice oportunitatea înființării oricărei persoane juridice, avizul dat având rol de acordare a personalităţii morale. Acest sistem al acordării personalității juridice a consacrat teoria ficțiunii în materie și s-a perpetuat și consolidat în timp, pe măsura creșterii intervenționismului statal. Mai mult, măsurile restrictive descrise s-au concentrat prioritar asupra fundațiilor - formă 
preferată de biserica catolică şi de corporațiile satelite acesteia ${ }^{12}$. Aşa se explică de ce Codul civil al lui Napoleon privea cu suspiciune orice încercare mascată de a perpetua Vechiul Regim sub forma înființării unor persoane juridice fără scop patrimonial. Codul a stabilit că nicio persoană juridică nu există fără autorizare prealabilă, iar fundațiile nici măcar nu sunt reglementate în cuprinsul său.

Comisiile care au lucrat la primul cod civil român în perioada 18591864 au preluat tehnica și concepția legislativă napoleoniană în materia examinată. Gestul este explicabil, dacă ținem cont de câteva realități ale epocii. Influența franceză era dominantă în toate sectoarele vieții din Principatele Unite românești. Majoritatea juriştilor români studiaseră dreptul la Paris, cea mai bună facultate de drept din lume la acel moment. Codul francez era ca un soare strălucitor în sec. XIX, fiind - de la Iustinian și până în acel moment - prima codificare de înaltă ținută din spațiul juridic european.

Poziția legislativă ostilă fundațiilor, importată din Franța, nu a găsit un teren fertil în România. Există două motive conjugate pentru a înțelege constatarea astfel formulată:

- codul civil al lui Cuza a fost timp de multe decenii o literă moartă pentru populația covârşitor rurală, care se conducea în mare măsură după reguli cu notorietate multiseculară ${ }^{13}$;

\footnotetext{
12 V. în acest sens și aprecierile lui M. Rădulescu, în La fondation privé (Stiftung) dans le droit allemand, tezxă, Paris, 1924, p. 113.

13 C.G. Disssescu, L influence du code civil français en Roumanie, în Le Code civil 1804-1904. Livre du centenaire, vol. II, Paris, p. 861-862; v. și M.D. Bocșan, „Redactarea Codului civil român din 1865", in "Studia Universitatis Babeş-Bolyai, series Iurisprudentia” nr. 1/2003, p. 72-75, online la adresa https://studia.law.ubbcluj.ro/articol/736
}

\section{0}


- tradiția din fostele Principate extracarpatice mergea de prea multe secole în sens contrar teoriei ficțiunii ${ }^{14}$. Astfel se explică de ce practica noastră judiciară a validat legatul făcut în favoarea unei fundații inexistente la data deschiderii succesiunii. Tradiția vechiului drept românesc a fost urmată nu numai de particulari ${ }^{15}$, ci chiar şi de regele Carol I ${ }^{16}$, în pofida prevederilor legislației civile (art. 475 alin. 2, art. 811 și 817 c.civ. 1864) şi ale Constituției $\operatorname{din} 1866^{17}$.

\section{Succesiunea Otetelișanu}

Lucrurile au mers mai departe odată cu o cauză celebră în sec. XIX: succesiunea Otetelişanu ${ }^{18}$. În testamentul acestuia redactat în 1876 se putea citi următoarea clauză: „După încetarea din viață a soției mele, întreaga mea avere va servi la facerea unui Institut de fete românce, cărora li se va da o creștere și educație de mame de familie, fără pretenție sau lux; prisosul ce va rămânea după bugetul anului se va capitaliza spre a se da zestre acestor

\footnotetext{
${ }^{14}$ Pentru detalii asupra acestei tradiții, v. articolul meu Etude historique sur les fondations testamentaires en droit roumain, în Forum historiae iuris, 27.III.2000, https://forhistiur.net/2000-03-dan-bocsan.

${ }^{15}$ De exemplu: Ateneul Român a fost înființat prin două donații făcute de persoane particulare în 1872 şi 1884, legea de recunoaștere (nu de acordare) a personalității juridice este adoptată la 31 martie 1886, iar Statutul Societății „Ateneul Român” are data de 29 noiembrie 1922 (a se vedea Legea nr. 1112/31.03.1886, publicată în M. Of., Partea I, nr. 4/4.04.1886, p. 50, respectiv art. 1 din Statutul Societății „Ateneul Român”, publicat în M. Of., partea I, nr. 189/29.11.1922). 16 „Fundația Universitară Carol I” s-a înființat în urma scrisorii din 3 mai 1891 a Regelui către președintele Consiliului de miniștri și i s-a recunoscut personalitatea juridică prin Legea din 4 iulie 1891, publicată în M. Of., Partea I, nr. 81/1891.

17 Art. 27 din Constituția de la 1866 prevedea: „Românii au dreptul de a se asocia, conformându-se regulilor care regulează exercițiul acestui drept”.

${ }^{18}$ Dosarul cauzei este complet redat în Bocșan, Practica..., cit.supra, p. 36-53.
}

\section{1}


fete, care nu va fi nici mai mult nici mai puțin decât două sute galbeni uneia, No. 200\#”. Era un caz tipic de înființare a unei fundații pe cale testamentară. Testatorul, consiliat de un prieten jurist (Ioan Kalinderu' ${ }^{19}$ ), a dorit să preîntâmpine dificultățile inerente teoriei ficțiunii mai sus expuse și a inclus în testament următoarea clauză: „În cazul în care s-ar susține și admite de orice persoane interesate, că legatul averii mele imobile, pe care-l fac acestui Institut, care se va crea, este nul, fie pentru că este făcut unui stabiliment care nu va avea în fapt o existență materială în momentul încetării mele din viață, fie pentru orice altă nulitate s-ar putea invoca în contra acestei dispoziții a înființării aşezământului mai sus arătat, în asemenea caz, zic, legatul în întregul său va fi privit ca făcut direct Dlui Ioan L. Calinderu, cu îndatorire şi rugăciune ce-i fac de a îndeplini în întreg dispozițiile mele sus arătate în privința înființării stabilimentului”"

Tribunalul Ilfov a trimis în posesie în 1889 pe Kalinderu asupra întregii averi a defunctului Otetelişanu. Moștenitorii legali au atacat în instanță testamentul pe motivele prevăzute de dispunător, precum și pe altele. Aceştia au solicitat invalidarea în principal pentru că dispoziția de înființare a fundației prin singură voința testatorului ar fi nulă. Reclamanții considerau tot nulă şi dispoziția în favoarea lui Kalinderu, care ar fi un simplu interpus sau - mai degrabă - un executor testamentar prin care dispunătorul voise să facă indirect ceea ce nu putea face direct: fondarea unei persoane juridice prin singură voința sa de persoană fizică. În fine, au argumentat şi faptul că tradiția vechiului drept românesc ar fi mers în sensul susținerilor lor.

${ }^{19}$ Licențiat în drept la Paris, cunoscut filantrop provenit dintr-o familie de bancheri turci stabiliți în Valahia, administrator al Domeniilor Coroanei și sfetnic al regelui Carol I, fondator al stațiunii Bușteni și primul traducător în limba română a Legii celor XII Table. 
Am arătat detaliat într-un studiu publicat cu mult timp în urmă de ce ultimul argument nu poate fi primit ${ }^{20}$. Am precizat oricum şi mai sus faptul că vechiul nostru drept nu impunea autorizarea prealabilă a fundațiilor testamentare (în sens de persoane juridice) prin vreun act al puterii centrale. Curtea de casație a dat o decizie de pionierat în ce privește celelalte două susţineri principale:

„Considerând că din definiția legii (art. 888 C.civ.), că legatul universal e dispoziția prin care testatorul lasă la moarte-i, la una sau mai multe persoane, universalitatea bunurilor sale, rezultă că pentru ca o persoană să poată fi privită juridic, ca legatară universală, se cere ca ea să aibă vocație, să fie adică chemată, ca după încetarea din viață a testatorului oi ca continuatoare juridică a persoanei acestuia în ceea ce priveote patrimoniul, să vadă intrând în patrimoniul său, întreg patrimoniu al persoanei decedate; că pe lângă această intrare a averii testatorului în patrimoniul legatarului legea nemaicerând, ca condiție a existenței calității de legatar, ca averea legată să și rămână în patrimoniul legatarului, se învederează că profitul pecuniar al acestuia, emolumentul, cu toată importanța lui practică din punctul de vedere al acceptării sau refuzului legatelor, nu a fost privit de lege ca condiție esențială a validității lor juridice; că prin urmare, în dreptul nostru civil, o persoană, căreia testatorul transmite, ca un continuator al său juridic, întreg patrimoniul său, e în toată puterea legală a cuvântului un legatar universal supus, o dată legatul acceptat, tuturor drepturilor și îndatoririlor inerente acestei calități, abstracție făcând de împrejurarea că, în condițiile în care e făcut legatul, sarcina ar exclude a priori orice idee de emolument.

Că aşa fiind, decizia atacată nu violează legea, când declară că Ion Otetelişanu a putut valabil institui pe Ion Kalinderu legatar universal al său cu sarcină ca întreaga avere legată să o consacre institutului de care e vorba în testamentul său.

Considerând că pe cât e de exact în drept că ceea ce legea oprește a se face direct nu se poate face nici indirect, pe atât este și adevărat că

\footnotetext{
${ }^{20} \mathrm{~V}$. și numeroasele exemple documentare și extrase din pravile, respectiv concluziile rezultate din analiza acestora, pe care le-am oferit în Bocşan, Etude ..., cit.supra.
} 
ceea ce legea permite să se facă se poate îndeplini prin orice mijloc, fie direct, fie indirect, cu condiția subînțeleasă ca mijlocul întrebuințat să fie și el permis, că așa fiind nu se poate declara nul un legat care conține ca sarcină pentru legatar împlinirea unui fapt pe care însuși testatorul l-ar fi putut săvârși în viață fără ca prin aceasta să se aducă o arbitrară atingere libertății de a testa; că prin urmare dacă netăgăduit fiind că ori ce persoană poate, trăind să facă a se da viață, ființă juridică, unei instituții permisă de lege, s-o organizeze și s-o înzestreze în condiții de asemenea permise, legea nu se opune ca această facultate, ca acest drept civil, să se transmită prin act de ultimă voință de la o persoană la alta; că în speță curtea de apel privind cu drept cuvânt că sarcina impusă de Otetelișanu lui Kalinderu constă în a fonda și înzestra un institut de creștere, educație și înzestrare de fete române, $n$-a violat legea validând legatul și din punctul de vedere al caracterului licit al sarcinii.

(...) Considerând cã existența unui legat universal cu sarcinaă, atârnând de condiția capacității legatarului și de aceea a naturii licite a sarcinii, Curtea de apel valideazaă legatul recunoscând în speță existența ambelor acestor condiții și declară pe legatar în drept și obligat prin testament, nu de a crea o persoană morală, ci de a face ca prin mijloacele legale și cu autorizația Statului să se dea ființă juridică aşezământului ce e chemat să înzestreze". ${ }^{21}$

Instanța de recurs a admis deci validitatea fundației testamentare, urmând astfel tradiția vechiului drept românesc, venind în continuarea practicilor cotidiene ale epocii și, nu în ultimul rând, înfrângând nepotrivita și desueta ostilitate a codificării de inspirație franceză față de persoanele juridice în general, față de fundații în speță.

\footnotetext{
${ }^{21}$ Cas. I, dec. 74/2.III.1892, în Bul. 1892.83 și Dr. 1892.199, redată în Practica..., cit.supra, p. 52-53.
} 


\section{Consacrarea legislativă a fundațiilor testamentare}

Soluția dată în cauză a fost un argument jurisprudențial important pentru consacrarea legislativă prin art. 71 L. 21/1924 a retroactivităţii fundațiilor înființate prin testament (dar și prin donații) ${ }^{22}$. Dispoziția a fost preluată în art. 19 al. 3 OG 26/2000 și o regăsim în actualul art. 208 c.civ. Sub aspectul practicii, tradiția de favoare faţă de activitatea fundațională este urmată și astăzi, mărturie stând decizia de validare a constituirii fundației Cella Delavrancea. În speță, testatoarea lăsase toată averea sa unei persoane de încredere, cu sarcina de a înființa o fundație. Legatara universală a Cellei Delavrancea şi-a dat seama că nu va putea să ducă la bun sfârşit sarcina asumată, astfel că a înstrăinat încă din timpul vieții bunurile primite unor persoane care, la șapte luni după decesul legatarei, au reușit să o înființeze. ${ }^{23}$

Se observă cum cauza relatată a avut circumstanțe juridice similare cu cele generate de testamentul Otetelișanu: un legat universal cu sarcina fondării. Cadrul legislativ instaurat începând din 1924 a urmărit și urmărește de fapt să asigure validitatea legatului fundațional, chiar şi în ipotezele extreme în care testatorul lipsit de succesori sezinari s-a rezumat să instituie un executor testamentar (sau chiar dacă nu a făcut nici măcar atât).

22 „Dacă fundația între vii sau testamentară este recunoscuta persoana juridică după moartea fondatorului, efectele liberalităților făcute anterior recunoaşterii se vor produce pentru fundațiile între vii de la data actului autentic de fundație; iar pentru fundațiile testamentare de la data morții testatorului.

Același efect îl vor avea liberalitățile făcute în timpul vieții fondatorului, anterior însă recunoașterii calității de persoana juridică”.

${ }^{23}$ CSJ civ., dec. 2203/31.V.2002, în PR 2/2003.143-146. Decizia este redată în subsolul paginii, în paralel cu soluția primei instanțe (Trib. București III civ., sent. 1013/5.X.2000), pe care o menține aproape integral. 
VII. Există continuitate în asigurarea unui cadru legal adecvat pentru încurajarea și validarea fondărilor testamentare?

Se poate acum răspunde la întrebarea cu care am pornit: există continuitate în asigurarea unui cadru legal adecvat pentru încurajarea și validarea fondărilor testamentare?

Fundația testamentară a fost văzută favorabil și practicată fără probleme până la adoptarea vechiului cod civil. Nici absența unei reglementări exprese și precise, nici lipsa unei teoretizări a conceptelor juridice implicate nu a impietat asupra fondărilor pioase sau caritabile. Am văzut apoi că momentul 1 decembrie 1865 a fost descurajant legislativ, dar nu și practic. Totuși, absența reglementărilor în materie a permis litigii precum cel care a opus pe legatarul (executorul) Kalinderu moștenitorilor legali ai testatorului Otetelişanu. Presiunile de diverse naturi exercitate de ultimii l-au făcut pe Kalinderu să dispere și să lase în 1905 Academiei Române toată averea primită, cu sarcina de continuare a institutului cu tot. Problema a fost că el a și înființat Institutul la Turnu Măgurele, dar fără a cere în prealabil acordul Academiei, al cărei președinte a fost din anul 1904 până în 1907. Înaltul for nu a mai dorit să continue ceea ce fusese inițiat, astfel că moștenitorii lui Otetelișanu au reușit în final să pună mâna pe imensa avere a antecesorului lor şi proiectul fundațional s-a năruit.

Se înțelege acum de ce Legea din 1924 și reglementările care au preluat-o ulterior au fost benefice pentru asigurarea unui cadru legal favorabil fundațiilor testamentare. Acest cadru se completează cu legislația fiscală, care enunță o listă de venituri neimpozabile din cele specifice activității fundației şi diverse stimulente fiscale pentru cei care contribuie dezinteresat la patrimoniul unei fundaţii. 
Singura problemă ar fi una de ordin practic, generată de armonizarea codului civil și OG 26/200o cu legislația notarială. Este posibil ca, într-un dosar succesoral concret, testatorul să nu aibă niciun moștenitor sezinar, să lase toată averea pentru înființarea unei instituții caritabile și să prevadă în testament numai un executor testamentar. Notarul public nu poate elibera un certificat de legatar pentru o entitate momentan inexistentă, chiar dacă art. 208 c.civ. face să retroactiveze capacitatea fundației ulterior înființate de a primi liberalităţi încă de la data deschiderii succesiunii. Ca urmare, notarul va emite un certificat de executor testamentar și ulterior, după înființarea fundației de către executorul desemnat, va putea elibera certificatul de legatar pentru aceasta. 